\title{
IPTEKS PENINGKATAN JUMLAH NASABAH PADA PT. BANK RAKYAT INDONESIA (PERSERO) TBK KCP UNIT UNSRAT MANADO
}

\author{
Eirene Lorensia Makisanti ${ }^{1}$, Sherly Pinatik ${ }^{2}$ \\ ${ }^{1,2}$ Jurusan Akuntansi, Fakultas Ekonomi dan Bisnis, Universitas Sam Ratulangi, Kampus Unsrat, Sulawesi Utara, \\ 95115, Indonesia \\ E-mail : elorensia10@yahoo.com
}

\begin{abstract}
Bank is a people trusted financial institution which holds an important role in the economic system. Promotion is one of the most effective ways to atrract and maintain the customers. It can inform the customer about the products and influence their preferences. The strategy of sale promotion is a process of planning a company's activities to reach its marketing goal, that is to increase the income and the sales volume, by influencing the purchase decision of the target customers. The method applied is an implementation of promotional strategy in order to increase the number of customers at Bank Rakyat Indonesia KCP Unit Unsrat Manado. The technique used was analyzing the promotional strategies utilized advertisements, face to face service, publications, and service promotions. It was found that the promotional strategies implemented increased the number of customers at Bank Rakyat Indonesia KCP Unit Unsrat Manado
\end{abstract}

Keywords : promotions, promotion strategies, increasing customers

\section{PENDAHULUAN}

Perbankan merupakan suatu lembaga keuangan kepercayaan masyarakat yang memegang peranan sangat penting dalam sistem perekonomian, sehingga dapat dikatakan bank merupakan pusat dari sistem keuangan yang berfungsi untuk menerima simpanan dari berbagai kalangan masyarakat baik itu dalam bentuk tabungan, depositi, giro, dll. Sebagai badan usaha yang bergerak dalam bidang jasa, suatu kepercayaan dari semua pihak adalah hal yang sangat penting baik bagi pemilik dan pengelola bank maupun masyarakat sebagai pengguna jasa bank dalam hal ini nasabah. Dalam sebuah perusahaan perbankan menyediakan berbagai macam layanan yang ditujukan untuk digunakan oleh nasabah. Namun bagaimana cara untuk mengimplementasikan atau memperkenalkan layanan tersebut kepada setiap nasabah yang tentunya membutuhkan yang namanya strategi promosi.

Promosi merupakan sarana yang paling ampuh untuk menarik dan mempertahankan nasabahnya yang bertujuan untuk menginformasikan segala jenis produk yang ditawarkan dan mampu mempengaruhi nasabah untuk dapat tertarik dengan apa yang ditawarkan sehingga dapat meningkatkan citra dari perusahaan perbankan itu sendiri. Dengan promosi yang baik tentunya akan menimbulkan citra yang baik pula bagi masyarakat sehingga mengakibatkan meningkatnya kualitas dan keuntungan perusahaan perbankan yang tentunya dibarengi dengan kualitas pelayanan yang terbaik. Ketika pelayanan yang diberikan memberikan rasa nyaman terhadap setiap nasabah untuk mampu menjaga hubungan yang baik dengan perusahaan perbankan sehingga memudahkan perusahaan untuk memahami kebutuhan dan harapan dari nasabah.

\section{TINJAUAN PUSTAKA}

Pengertian Bank. Menurut UU No. 10 tahun 1998 definisi Bank merupakan suatu usaha perbankan yang menghimpun atau memgelola dana masyarakat berupa simpanan giro, deposito berjangka, tabungan kemudian dapat disalurkan dalam bentuk kredit kepada 
masyarakat atau bentuk lainnya untuk menaikan taraf hidup masyarakat. Menyalurkan dana dan menghimpun dana ialah kegiatan pokok dari bank sedangkan kegiatan pendukung dari bank yaitu memberikan jasa bank berdasarkan thesis Mufarroha, 2016.

Strategi. Menurut Siagin (2004) Strategi merupakan tindakan dan keputusan yang mendasar yang telah dibuat manajemen puncak \& dipraktekan kepada suatu organisasi atau seluruh jajaran untuk pencapaian dari tujuan organisasi tersebut.

Promosi Penjualan. Tjiptono (2001:219) promosi merupakan proses komunikasi pemasaran yang dijalankan untuk memberikan informasi secara luas, memberi pengaruh, serta mengingatkan target pasar kepada perusahaan dan produk supaya mau menerima, melakukan pembelian dan loyal kepada barang dan jasa yang ditawarkan perusahaan. Kotler (2002) Definisi promosi ialah rangkaian aktivitas yang dijalankan perusahaan dengan menunjukkan kelebihan-kelebihan produknya serta mempengaruhi target konsumen supaya melakukan pembelian.

Strategi Promosi. Fandy Tjiptono strategi promosi penjualan adalah perencanaan aktivitas yang dilaksanakan dalam rangka peningkatan permintaan dari para konsumen untuk meningkatkan volume dan omset penjualan. Aktivitas tersebut dilakukan dengan mempengaruhi secara langsung konsumen dalam keputusan pembelian. Meokijat (2000: 443) promosi strategi merupakan kegiatan suatu perusahaan dalam mendorong penjualan dengan cara pengarahan komunikasi-komunikasi untuk meyakinkan kepada para pembeli. Berdasarkan pernyataan diatas kedua ahli tentang strategi promosi sehingga dapat diambil kesimpulan bahwa strategi promosi merupakan aktivitas yang dilakukan untuk meningkatkan volume permintaan dari para konsumen dan meningkatkan kualitas penjualan dengan cara meyakinkan para nasabah. Dan yang menjadi tujuan utama dari strategi promosi ialah terciptanya peningkatan suatu permintaan dari nasabah terhadap layanan dan peningkatan performa dari perusahaan. Adapula beberapa tujuan pokok dari strategi promosi terhadap produk atau layanan perbankan, yaitu :

1. Meningkatkan Volume Penawaran dan Produksi. Ketika nasabah merasa tertarik dan berminat dengan promosi yang ditawarkan akan menibulkan permintaan terhadap suatu layanan. Peningkatan permintaan akan meningkatkan volume penawaran setelahnya.

2. Menambah Repeat Order. Contohnya dengan memberikan voucher berisi penawaran diskon pada transaksi berikutnya.

3. Menumbuhkan Loyalitas Pelanggan. Yaitu dengan cara memberikan promosi secara berkesinambungan.

4. Meningkatakan daya tarik strategi. Promosi harus dilakukan agar rasa ketertarikan pelanggan menetap pada satu layanan. Melalui promosi yang kontinyu maka pelanggan akan merasa bahwa produk yang mereka gunakan tetap up to date.

5. Membentuk Kesadaran. Yaitu contohnya dengan menawarkan pelayanan jasa kredit kepada nasabah yang dapat membantu kebutuhan dari nasabah

\section{METODE DAN TEKNIK PENERAPAN IPTEKS}

\subsection{Metode Penerapan Ipteks}

Metode yang diterapkan yaitu menganalisa peningkatan jumlah nasabah melalui strategi promosi.

\subsection{Teknik Penerapan Ipteks}

Teknik penerapan ipteks yang dilakukan yaitu menganalisa strategi promosi berdasarkan kegiatan yang dilakuakan yaitu periklanan, pelayanan dengan tatap muka, publikasi, dan promosi pelayanan. 


\section{PEMBAHASAN}

4.1. Gambaran Objek

PT. BRI (Persero) adalah satu bank terbesar diindonesia milik pemerintah yang berkedudukan di Jalan Jenderal Sudirman Kav. 44-46 Jakarta. BRI ini didirikan di Purwokerto, Jawa Tengah oleh Raden Bei Aria Wirjaatmadja dengan nama Bank Bantuan dan Simpanan Milik Kaum Priyayi Purwokerto yang artinya suatu lembaga yang memberikan pelayanan orang pribumi atau orang berkebangsaan Indonesia. Didirikan pada tgl 16 Des 1895 kemudian ditetapkan sebagai hari kelahiran BRI. Berdasarkan PP No. Pasal 1 No.1 thn 1946 bahwa BRI merupakan Bank pertama Pemerintah di Indonesia. Tahun 1960 berdasarkan PERPU No. 41 terbentuk BKTN merupakan peleburan dari BRI. Setelah mengalami beberapa putusan, pada tgl 1 Agustus 1992 berdasarkan UU Perbankan No. 7 thn 1992 dan PP RI tahun 1992 No. 21 status BRI berubah menjadi Perseroan Terbatas yang pada waktu itu kepemilikan Bank Rakyat Indonesia ditangan pemerintah RI masih $100 \%$. Kemudian pada thn 2003 Pemerintah RI telah memutuskan menjual 30\% dari kepemilikan saham yang kemudian dijadikan perusahaan publik degan nama yang resmi PT. BRI (persero) dan samapi saat ini masih ada.

\subsection{Pembahasan}

\section{Strategi Promosi Sebagai Upaya Peningkatan Nasabah pada PT. Bank Rakyat Indonesia Kcp Unit Unsrat Manado}

1. Advertising (Periklanan) pelaksanaan yang telah dilakukan oleh Bank Rakyat Indonesia Kcp Unit Unsrat sudah memenuhi standart yang ditetapkan. Periklanan yang ada dalam perbankan ialah berisi suatu penawaran dalam bentuk gambar-gambar atau tayangan \& kata-kata yang tertuangkan dalam koran, brosur, spanduk, majaah dll ditujukan kepada para nasabah yang ingin dan tertarik untuk mencoba transaksi tersebut. Advertising atau iklan yang di tawarkan Bank Rakyat Indonesia Kcp Unit Unsrat memang telah dibuat terlebih dahulu dari kantor pusat seperti halnya design, promosi apa yang akan ditawarkan, dalam bentuk seperti apa yang tinggal disalurkan ke seluruh bank-bank BRI yang ada. Periklanan yang ditawarkan oleh Bank Rakyat Indonesia Kcp Unit Unsrat telah dibuat dan dilakukan secara baik dan mudah dijangkau oleh masyarakat khususnya nasabah dan muatan yang tertera dapat dengan mudah dipahami serta menarik untuk dilihat oleh masyarakat.

2. Personal Selling (Penjualan/Pelayanan tatap muka) bentuk promosi ini telah diterapkan pada Bank Rakyat Indonesia Kcp Unit Unsrat dan pada umumnya perusahaan perbankan di seluruh indonesia telah menerpkan promosi ini. Sehari -hari proses bentuk promosi pelayanan tatap muka terjadi di Bank Rakyat Indonesia Kcp Unit Unsrat dengan melalu proses transaksi. Dalam hal ini jasa layanan yang digunakan oleh Bank Rakyat Indonesia Kcp Unit Unsrat ialah Customer Service, ketika nasabah melakukan transaksi Customer Service bisa menjelaskan langsung secara rinci mengenai produk bank. maupun kebutuhan yang diinginkan oleh nasabah. Terdapat sedikit kendalah dalam hal kegiatan personal selling ini, dalam hal waktu, mengingat kurangnya Custumer Service di Bank Rakyat Indonesia Kcp Unit Unsrat dimana Bank Rakyat Indonesia Kcp Unit Unsrat hanya bagian dari kantor cabang yang disebut Unit, dan nasabah terlalu banyak di BRI Kcp Unit Unsrat karena berada diantara berbagai macam fakultas baik mahasiswa maupun para dosen dan pegawai membuat para jasa layanan nasabah tidak bisa meninggalkan pelayanan jasa hanya menggunakan sistim pergantian.

3. Publisitas (publisity) publisitas sendiri merupakan dimana berlangsungnya promosi bertujuan untuk menarik nasabah melalui kegiatan pameran. promosi di sponsorship kegiatan, dan masih banyak lagi. Dan Bank Rakyat Indonesia Kcp Unit Unsrat Manado telah banyak melakukannya yaitu ketika hari - hari besar seperti dalam rangka Hut BRI, kemudian acara yang diselenggarakan oleh Bank Indonesia untuk seluruh perusahaan 
perbankan di indonesia yang dibuat di pusat perbelanjaan. Dan kegiatan ini membuat Bank Rakyat Indonesia Kcp Unit Unsrat manado banyak dikenal di berbagai kalangan terlebih khusus masyarakat yang berada di sekitar Bank Rakyat Indonesia Kcp Unit Unsrat yang dengan mudah dan terjangkau untuk melakukan transaksi dalam hal ini para dosen, pegawai, dan mahasiswa. Ketika Bank Rakyat Indonesia Kcp Unit Unsrat mengikuti kegiatan ini maka yang akan bertanggung jawab atau yang akan diutus pelayanan jasa yaitu 1 customer service dan 1 bagia Kerdit kemudian secara bergantian sesuai arahan dari pimpinan.

4. Sales Promotion (Promosi Penjualan/Pelayanan) kegiatan sales promotion ini juga telah dilakukan dengan baik oleh Bank Rakyat Indonesia KCP Unit Unsrat manado yang dilakukan baik ketika ada event di pusat perbelanjaan ataupun dalam melakukan transaksi dengan nasabah, jasa layanan yang diberikan dalam hal ini Customer Service dapat secra langsung menawarakn promosi yang ada. Promosi yang diberikan ialah dalam bentuk berupa kupon atau pemberian diskon. Setelah melakukan kegiatan promosi ini Bank Rakyat Indonesia Kcp Unit Unsrat Manado akan menyusun kesesuaian penawaran dan kemudian melakukan pengujian dan melaksanakan program atau promosi yang ditawarkan serta setelahnya mengevaluasi hasil akhir dari kegiatan promosi pelayanan jasa tersebut.

Ketika kegiatan dari strategi promosi di atas telah terlaksana dengan baik, sesuai dengan prosedur yang ditentukan maka dapat diukur peningkatan nasabah pada PT. Bank Rakyat Indonesia (Persero) Tbk Kcp Unit Unsrat.

\section{KESIMPULAN DAN SARAN}

\subsection{Kesimpulan}

Sesuai hasil yang didapat bahwa strategi promosi yang di terapkan Bank Rakyat indonesia Kcp Unit Unsrat, seperti kegiatan promosi yang dilakukan sesuai dengan harapan para nasabah, maka Bank Rakyat indonesia Kcp Unit Unsrat mampu memberikan pelayanan dan memenuhi kebutuhan nasabah dan tentunya melalui proses pelayanan yang terbaik, ramah, sopan, dan mampu menjelaskan dengan baik keinginan dari nasabah. Terdapat sedikit kendala pada kegiatan personal selling atau pelayanan tatap muka dimana waktu dari pelayanan jasa atau Customer Servce tidak bisa meninggalkan jasa layanan nasabah hanya menggunakan sistim pergantian di waktu istirahat. Berdasarkan hasil yang didapat bahwa strategi promosi yang di terapkan mampu meningkatkan nasabah yang ada di PT. Bank Rakyat Indonesia (Persero) Tbk Kcp Unit Unsrat Manado.

\subsection{Saran}

1. Untuk Karyawan PT. Bank Rakyat Indonesia Kcp Unit Unsrat Manado untuk tetap mempertahankan keramahan dan kualitas pelayanan yang terbaik untuk nasabah.

2. Untuk PT. Bank Rakyat Inconesia Cabang Manado agar memberikan kesempatan kepada Customer Service untuk menikmati waktu istirahat yang sesuai dengan karyawan lainnya.

\section{DAFTAR PUSTAKA}

Herry Achmad Buchoriec dan Djaslim Saladin. 2006. Pemasaran Bank. Bandung : Linda Karya

Kothler Phillip. AB Susanto (1999). Manejemen Pemasaran di Indonesia. Jakarta: Salemba Empat

Kotler, Phillip. 2002, Manejemen Pemasaran, Edisi Milenium, Jilid 2, Penerbit Prehallindo, Jakarta

Kasmir , 2004. Bank Pemasaran. Jakarta : Kencana 
Marceline Livia Hedynata, 2016. Strategi Promosi Dalam Meningkatkan Penjualan Luscious Chocolate Potato Snack. Nomor 1, Volume 1, Halaman 87-96

Mufarroha, 2016. Analisis Perlakuan Akuntansi Atas Kredit Usaha Rakyat Mikro Pada Bri Unit Kapasan Surabaya. Diploma Thesis, Stie Perbanas Surabaya.

Moekijat. 2000. Manajemen Pemasaran. Bandung : Penerbit Penerjemahan David

Sondang P, Siagian, 2004. Menejemen Strategik. Terbitan Jakarta : Bumi Aksara

Tjiptono 2001, Strategi Pemasaran, Cetakan Kelima, Penerbit Andi, Yogyakarta.

Tjiptono, Fandy. (2002). Strategi Pemasaran Jasa. Yogyakarta : andi Ofiset

Undang - Undang Pemerintah RI No. 21 Thn 1992 tentang Penyesuaian Bentuk Hukum BRI menjadi Perusahaan Perseroan.

Undang - Undang RI No. 10 Thn 1998 tentang Perbankan 